\title{
LIGHTWEIGHT GYPSUM BASED MATERIALS: METHODS OF PREPARATION AND UTILIZATION
}

\author{
MAGDALENA DOLEŽELOVÁ, JITKA KREJSOVÁ \& ALENA VIMMROVÁ \\ Faculty of Civil Engineering, Department of Materials Engineering and Chemistry, \\ Czech Technical University in Prague, 16629 Prague 6, Czech Republic.
}

\begin{abstract}
Although gypsum is one of the most environmentally friendly building binders, its use in the buildings is relatively limited and therefore the broadening of the gypsum product portfolio is desirable. One possibility is the development of the lightweight gypsum materials with better thermal insulation properties, attractive acoustic properties and also lower transportation costs. The lightweight gypsum materials can be used in a similar way as an aerated autoclaved concrete (AAC), whose energy consumption at production is several times higher.

The main methods of the preparation of gypsum-based lightweight materials are described and compared. Gypsum can be lightened indirectly by the lightweight filler or directly. In the directly lightened materials, the pores are introduced into the gypsum material either by some chemical reaction producing gas or by the help of surface active substances. For the chemical lightening a large scale of waste products can be used. Lightening by the help of waste stone powder is described in detail. The materials with the properties comparable with the properties of AAC were prepared. Their bulk density was under $600 \mathrm{~kg} / \mathrm{m}^{3}$, compressive strength was about $2 \mathrm{MPa}$ and coefficient of thermal conductivity was under $0.2 \mathrm{~W} / \mathrm{m} . \mathrm{K}$.

Lightweight gypsum materials can be used as a thermal insulating blocks, for the lightweight gypsum boards, partitions blocks, lightweight fire-resistant plasters or thermal-insulating plasters.

Keywords: AAC, chemical lightening, direct lightening, gypsum, indirect lightening, inorganic filler, lightening methods, organic filler, SAS, waste products.
\end{abstract}

\section{INTRODUCTION}

The calcined gypsum $\left(\mathrm{CaSO}_{4} \cdot 0,5 \mathrm{H}_{2} \mathrm{O}\right)$ is one of the most environmentally friendly and sustainable building binders. The energy consumption necessary for gypsum production is very low, compared to the energy consumption of cement and lime production. Gypsum can be also made from large scale of waste products, originating e.g. in the fertilizers production (phosphogypsum) [1] or in the coal power plants from flue gas desulfurization (FGD gypsum) [2].

Another advantages of gypsum are excellent fire-protecting properties, good workability and aesthetics. In spite of its advantages, the current utilization of gypsum in buildings is limited mostly to the interior plasters, self levelling floors and gypsum boards. Therefore, the development of the lightweight gypsum-based materials may be considered as a good contribution to the larger utilization of this interesting material. The lightweight materials are preferred nowadays because they have better thermal insulation properties, favourable acoustic properties and lower transportation costs.

Even solid gypsum are not considered as a heavy material, its bulk density usually ranges between 1,000 and $1,500 \mathrm{~kg} / \mathrm{m}^{3}$, however, the bulk density under $1,000 \mathrm{~kg} / \mathrm{m}^{3}$ have to be achieved by some lightening method. 
Methods, used for the gypsum lightening, are similar to the methods, used for lightening of other building binders, although it is necessary to take into consideration the different behaviour and chemical composition of the gypsum-based binders.

\section{INDIRECT LIGHTENING}

The simplest method to prepare lightweight material is the use of the lightweight fillers that can be added to the gypsum paste. This method is largely applied in the production of the lightweight concretes, but for gypsum-based materials is not so common. The fillers are not usually added to the gypsum paste, they are not necessary here since the gypsum does not shrink during the setting (contrary to cement and lime). Nevertheless, the indirect lightening of the gypsum-based materials is used, although in the smaller extend than in the cementbased materials. As a lightweight filler both the inorganic and organic materials can be used. Utilization of inorganic fillers is advantageous from the point of fire resistance, but the organic materials are usually lighter and less expensive.

\subsection{Inorganic fillers}

The most common fillers in the commercially available products are expanded perlite and vermiculite. Perlite is an amorphous volcanic glass and vermiculite is phyllosilicate mineral, both of them contain relatively high amount of bound water and when subjected to heat, they expand and create very lightweight aggregate. The bulk density of the gypsum with inorganic fillers is usually higher than $800 \mathrm{~kg} / \mathrm{m}^{3}$, exceptionally the materials with the lower bulk density (under $300 \mathrm{~kg} / \mathrm{m}^{3}$ ) are commercially available.

Demir and Baspinar [3] put the perlite in the amount of $5 \%-10 \%$ by mass into the fly ashlime-gypsum material with the silica fume addition. They obtained material with the bulk density about $730 \mathrm{~kg} / \mathrm{m}^{3}$ (i.e. ca $20 \%$ lower than material without perlite) and its compressive strength was $2.3 \mathrm{MPa}$. Genzel et al. [4] used the vermiculite together with the polypropylene fibres. With $20 \%$ of vermiculite they achieved only slight decrease of bulk density (about $10 \%$ ) at the strength loss about $30 \%$. The thermal conductivity decreased by $30 \%$.

As an interesting experiment seems to be use of the expanded silica gel granules. Baspinar and Kahraman [5] expanded silica gel at the temperature $1,200^{\circ} \mathrm{C}$. Expanded granules were then added in the amount $5 \%-15 \%$ by mass into the gypsum slurry. Considering the relatively high price of the silica gel and the high-energy consumption at the expanding process the material is not competitive on the market.

\subsection{Polymer fillers}

Large amount of polymer materials can be used as lightweight filler in the gypsum-based materials. The most common polymer for this purpose is foamed polystyrene, either new or recycled. Garcia Santos used non-recycled polystyrene beads together with the polypropylene fibres [6]. By addition of $2 \%$ of polystyrene and $2 \%$ of fibres he prepared material with the bulk density lower by $50 \%$ (comparing to pure gypsum) and with the tensile strength higher by $23 \%$. Author does not mention any problems with mixing or workability of the material, while Saiyl and Gurdal [7] state, that it was necessary to ad an epoxy resin to improve the contact of the polystyrene granules with the gypsum. It was probably caused by the fact that the polystyrene was added to the gypsum in the higher amount (about 5\%-7\%). Authors obtained material with extremely low bulk density $\left(200 \mathrm{~kg} / \mathrm{m}^{3}\right)$ but with the very low strength (0.18 MPa) also. González Madariaga and Lloveras Macia used the recycled polystyrene [8]. 
Interesting results were achieved by Gutierrez-Gonzales et al. [9] by utilization of the waste polyamide powder generated in an industrial laser sintering process. The material with the high amount of polyamide powder with the granulometry under $100 \mu \mathrm{m}$ (up to the volume ratio of the polyamide powder to the calcined gypsum 4:1) was prepared. Obtained bulk density of the tested materials was always higher than $750 \mathrm{~kg} / \mathrm{m}^{3}$.

Waste granulated polyurethane foam from automobile and construction industry was tested by the same authors [10]. The grounded polyurethane foam was added to the gypsum in the amount up to the volume ratio 4:1. Prepared materials had bulk density between 500 to $1,300 \mathrm{~kg} / \mathrm{m}^{3}$, but the compressive strength of the lightest materials was very low. Only materials with the amount of the polyurethane in the ratio to the volume of gypsum 1:1 and lower had a sufficient strength for some building purposes.

Another waste material, tested as filler in the gypsum materials, is ground rubber from used tyres. The strength of the materials with the rubber particles decreases significantly even with the relatively small amount of rubber about $5 \%$. Also the workability of the material was worse, and it was difficult to achieve a homogeneous distribution of rubber particles in the gypsum plaster [11]. Herrero et al. [12] tested the rubber particles with different granulometry and best results were achieved with the finest particles (size $0-0.6 \mathrm{~mm}$ ). Although the mechanical properties worsened, the thermal and acoustic properties were improved, namely the insulation capacity against both impact and airborne noise.

Rivero, et al. [13] used ground rubber from pipe foam insulation and also found that the final properties of the lightened material depend mostly on the granulometry of the particles. The best results were achieved with the finest fillers $(1-2 \mathrm{~mm})$.

\subsection{Natural fillers}

The fillers of natural origin (both vegetable and animal) have been used in the gypsum traditionally, mostly in the form of fibres. Some of them could also serve as lightweight fillers (chopped straw, sawdust).

Nowadays Hernández-Olivares et al. [14] used cork granules with the size under $12 \mathrm{~mm}$. Materials with the $20 \%$ of cork filler had bulk density about $800 \mathrm{~kg} / \mathrm{m}^{3}$ and very favourable compressive strength about $5 \mathrm{MPa}$. By the addition of $2 \%$ of glass fibres the tensile strength increased nearly two times.

\section{DIRECT LIGHTENING}

The term direct lightening is used when the pores are incorporated directly into the gypsum matter, either chemically or mechanically. The pores can be introduced into the gypsum material by gas-releasing chemical reaction or by mechanical frothing using surface active substances.

\subsection{Chemical lightening by gas}

There is significant difference between the chemical composition of the gypsum and other inorganic binders. Whereas cement and lime contain calcium hydroxide and are strong basis, gypsum $\left(\mathrm{CaSO}_{4} \cdot 0,5 \mathrm{H}_{2} \mathrm{O}\right)$ is neutral or mildly acid. Therefore the gas-releasing chemical reactions have to be different from the reactions, which are utilized for the lightening of the cement or lime.

As a foaming gas the carbon dioxide is used mostly, because there can be applied several suitable chemical reactions. The most common is the reaction of carbonate (or hydrocarbonate) with the acid component (1). 
As a carbonate component the calcium carbonate (e.g. in the form of chalk or grounded limestone or marble dust), sodium bicarbonate $\left(\mathrm{NaHCO}_{3}\right)$ or ammonium bicarbonate $\left(\mathrm{NH}_{4} \mathrm{HCO}_{3}\right)$ can be used $[15,16]$.

As an acid components mostly inorganic acids or salts are usually used (e.g. aluminium sulphate, sulphuric acid, boric acid) [17], but organic acid can be used also. Gamarra in the first patent concerning the chemically foamed gypsum [18] describes the acid component composed from tartaric acid and calcium chloride.

Typical reactions are the reaction of the aluminium sulphate with the calcium carbonate (1) or the decomposition of the ammonium bicarbonate in the water (2). The preparation of the lightweight gypsum foamed by gas released from this reaction can be seen at Fig. 1 .

$$
\begin{gathered}
\mathrm{Al}_{2}\left(\mathrm{SO}_{4}\right)_{3}+3 \mathrm{CaCO}_{3}+9 \mathrm{H}_{2} \mathrm{O} \rightarrow 2 \mathrm{Al}(\mathrm{OH})_{3}+3 \mathrm{CaSO}_{4} \cdot 2 \mathrm{H}_{2} \mathrm{O}+3 \mathbf{C O}_{2} \\
\mathrm{NH}_{4} \mathrm{HCO}_{3} \rightarrow \mathrm{NH}_{3}+\mathbf{C O}_{2}+\mathrm{H}_{2} \mathrm{O}
\end{gathered}
$$

From the environmental point of view there is no need to be afraid about the carbon dioxide formation, because the amount of it, produced by the reactions is negligible and moreover the most of $\mathrm{CO}_{2}$ stays enclosed in the pores of the solid material. On the contrary, the large scale of the waste products can be utilized in the reaction.

Another carbon dioxide producing reaction is the reaction of the isocyanate with water (3) [19]. Because the isocyanates are potentially dangerous irritants to the eyes and respiratory tract and are classified as potential human carcinogens, the reaction is not preferable.

$$
\mathrm{R}-\mathrm{NCO}+\mathrm{H}_{2} \mathrm{O} \rightarrow \mathrm{R}-\mathrm{NH}_{2}+\mathrm{CO}_{2}
$$

Less frequently the oxygen as a foaming gas is used. In the US patent [20], the gypsum slurry is foamed by the oxygen, produced by decomposition of hydrogen peroxide using a cobalt compound prepared by oxidation of a water soluble cobalt salt. Oxidation is effected by pretreating the cobalt salt with hydrogen peroxide in the presence of an alkali (4). Authors declare that produced materials have excellent sound absorption and the bulk density about $500 \mathrm{~kg} / \mathrm{m}^{3}$.

$$
2 \mathrm{H}_{2} \mathrm{O}_{2} \rightarrow 2 \mathrm{H}_{2} \mathrm{O}+\mathbf{O}_{2}
$$



Figure 1: Preparation of the chemically foamed gypsum in the mixer. 


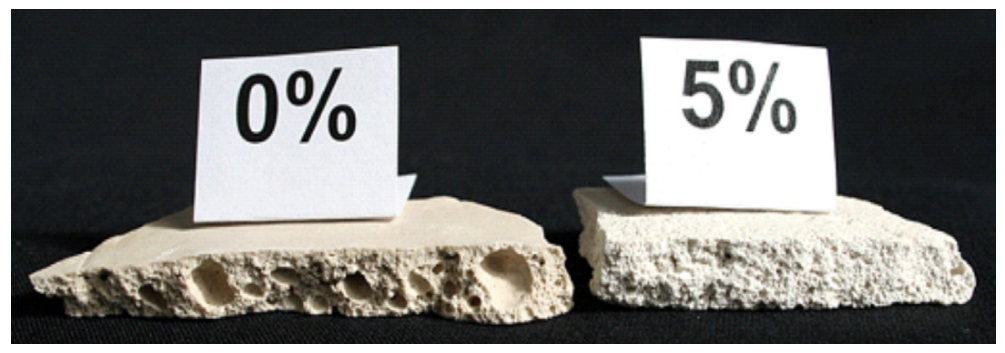

Figure 2: Structure of chemically foamed gypsum without perlite and chemically foamed gypsum with $5 \%$ of perlite.

The most common method for the preparation of the lightweight concretes is foaming by hydrogen, produced by reaction of the aluminium with the calcium hydroxide (5). By this method, the aerated autoclaved concrete (AAC) is produced.

$$
2 \mathrm{Al}+3 \mathrm{Ca}(\mathrm{OH})_{2}+6 \mathrm{H}_{2} \mathrm{O} \rightarrow 3 \mathrm{CaO} \cdot \mathrm{Al}_{2} \mathrm{O}_{3} \cdot 6 \mathrm{H}_{2} \mathrm{O}+3 \mathbf{H}_{2}
$$

Reaction (5) could not be used for the foaming of gypsum directly, because it needs the calcium hydroxide, and it occurs only in the alkali environment. Nevertheless the method can be used for the foaming of the compound binders, containing besides gypsum also calcium hydroxide (e.g. in cement or lime). In the first experiments, the material, prepared from the $65 \%$ of gypsum, $33 \%$ of hydrated lime and foamed by $1 \%$ of aluminium powder achieved the bulk density $640 \mathrm{~kg} / \mathrm{m}^{3}$, but its compressive strength was under $1 \mathrm{MPa}$ [21].

The main problem of the chemically foamed gypsum is less homogenous structure, because the released gas could sometimes create very large pores (larger than $5 \mathrm{~mm}$ ), which have negative impact on the mechanical and water transport properties. The problem can be solved by the addition of the small amount of the fine aggregate, preferably lightweight (e.g. perlite) [22]. The fine particles effectively break the big bubbles and the final structure is more homogenous (Fig. 2).

\subsection{Utilization of waste products for chemical lightening}

For the chemical reaction producing carbon dioxide as a foaming gas, the wide range of the waste products can be used. Any product containing sufficient amount of calcium carbonate can be utilized in the reaction. The use of the mud from sugar making production or the Class C fly ash was described in the several patents $[23,24]$.

We prepared the lightweight gypsum material, foamed by the help of the waste stone dust, which was used as a source of the calcium carbonate.

The amount of waste dust from cutting and polishing of stone became a serious problem in some countries, because it is mostly land filled yet. The dust usually contains some amount of the calcium carbonate, because there are a number of minerals with the high calcium carbonate content (e.g. marble, limestone, chalk or travertine) and therefore it can be used for foaming.

We used the stone dust, mostly constituted from marble and granite, from local stonemason producer (Kamenictví Jež, Beroun, Czech Republic). It was taken in the form of the sludge after the underwater cutting of the stones. The sludge was dried and then ground to the maximal particle size $100 \mu \mathrm{m}$. Amount of the calcium carbonate in the dust was $68 \%$, which was sufficient for successful foaming. 




Figure 3: Gypsum with the bulk density $460 \mathrm{~kg} / \mathrm{m}^{3}$ foamed by the stone dust.

As an acid component the aluminium sulphate was used and the reaction occurred according to reaction (1).

The materials with the amount of dust $8 \%-25 \%$ were prepared. The bulk density of prepared materials ranged from $460 \mathrm{~kg} / \mathrm{m}^{3}$ to $1000 \mathrm{~kg} / \mathrm{m}^{3}$ (Fig. 3). The material with the highest amount of dust achieved the bulk density $586 \mathrm{~kg} / \mathrm{m}^{3}$ and its compressive strength was $1.1 \mathrm{MPa}$. The mixture achieved also very favourable coefficient of thermal conductivity $0,082 \mathrm{~W} / \mathrm{m} . \mathrm{K}$, and therefore, it could be classified as thermally insulating material.

\subsection{Lightening by the surface active substances}

The lightening by the surface active substances (SAS), i.e. substances which lowers the surface tension can be performed by two methods. In the first method, SAS is added directly into the gypsum slurry, and then the mixture is intensively whisked at the high speed in the special mixing machine until the required bulk density is achieved. The second method lies in the use of the pre-prepared foam from foam generator. Then, the foam is either cautiously mixed into the gypsum slurry or the dry components are successively added into the foam. Lightening of gypsum by SAS is described in several patents and papers.

As a surface active substance, mostly the commercially detergents are used, mostly based on the sodium lauryl sulphate $[15,25]$. Also the substances, based on the common food additives methyl cellulose and iota carageenan gum were tested [26]. The Chinese patent [27] describes the complex foaming compound, containing sodium bisulfite, lauryl alcohol, maleic acid monoester sodium, sodium hydroxide, glue, horn powder, vegetable proteins, lauryl diethanolamine, gelatin, polyoxyethylene octyl phenol ether, lauryl dimethylamine acetate lactone, methyl glucoside dioleate.

Materials, lightened by the help of SAS have generally very low strength [26, 27], usually under $1 \mathrm{MPa}$, even when their bulk density is relatively high. Brencis et al. [28] tried to improve the mechanical properties by the addition of the hemp fibres. They achieved slight increase of the compressive strength (from 0.3 MPa to 0.5 MPa), but these values are not sufficient for the building purposes yet. Authors recommend to use the material as a part of the acoustic constructions because of its very good sound absorption. In this case the low mechanical properties are not such an issue. 

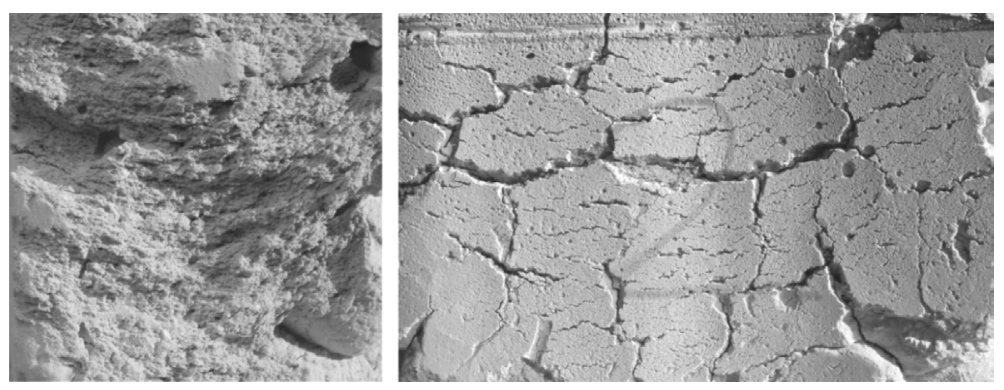

Figure 4: Failure of the material by the subsequently released gas.

\section{COMPARISON OF THE LIGHTENING METHODS}

The method of chemical lightening seems to be the most convenient, because the large scale of suitable gas-releasing reaction could be used and by the right choice and amount of the foaming additives the material with desired properties could be prepared. Moreover a lot of waste products could be used as foaming agents. The main disadvantage of the method is occasional formation of the large pores and therefore less homogenous structure of the foamed material. Also synchronization of the kinetics of the foaming reaction and setting of the gypsum matrix could be sometimes difficult. When the setting is finished before the gasreleasing reaction is terminated, the subsequently released gas could destroy the already solid, but insufficiently hardened material (Fig. 4).

The indirect lightening by the lightweight aggregates seems to be simple, but very often it is difficult to achieve uniform distribution of the particles, because they tend to cluster and rise to the surface. The advantage of the method is also in the large scale of the waste products, which can be used as a filler, but the utilization of the organic materials usually worsens the fire properties. The bulk density of the indirectly lightened materials is usually higher than the bulk density of the chemically foamed materials.

The mechanical properties of the materials, lightened by the help of SAS are mostly insufficient for the building purposes. This method is not preferable also because it requires the use of special equipment (foam generator or high-speed mixer).

\section{CONCLUSIONS}

Lightweight gypsum is a material resembling the AAC, and therefore, it can be used in similar way. The lightweight blocks and panels for walls, partitions and acoustic constructions could be made from it, similarly to the AAC. In addition to the interior thermal-insulating plasters, light weight fireproof plasters, ready-to-use dry mortars and the core of the thermal insulating gypsum boards may be also produced from the lightweight gypsum materials.

The main disadvantage of gypsum-based materials, compared to AAC is that gypsum could not be used in the wet environment. Gypsum is partially soluble in water and its strength decreases with the increasing moisture of the material, therefore the gypsum products have to be protected against water.

Nevertheless this disadvantage is compensated by the significantly better ecological and economical properties of the gypsum. In comparison, AAC is made from quicklime, burned from the limestone at the temperature about $1,000^{\circ} \mathrm{C}$. AAC also has to be autoclaved (cured in pressurized steam) to obtain final properties, so another energy demanding technology is 
utilized in its production. On the contrary, gypsum is prepared at the relatively low temperature under $200^{\circ} \mathrm{C}$, and it could be produced from several waste products (e.g. from FGD gypsum or phosphogypsum). Gypsum industry is also one of the forerunners in transformation to the circular economy in the construction industry, because gypsum products are indefinitely and fully recyclable. With regard to these facts the larger utilization of the gypsum-based products is highly desirable.

\section{ACKNOWLEDGEMENT}

This research has been supported by the Czech Science Foundation under project No. 16-01438S.

\section{REFERENCES}

[1] Degirmenci, N., Utilization of phosphogypsum as raw and calcined material in manufacturing of building products. Construction and Building Materials, 22(8), pp. 1857 1862, 2008. http://dx.doi.org/10.1016/j.conbuildmat.2007.04.024

[2] Tesárek, P., Drchalová, J., Kolísko, J., Rovnaníková, P. \& Černý R., Flue gas desulfurization gypsum: study of basic mechanical, hydric and thermal properties. Construction and Building Materials, 21(7), pp. 1500-1509, 2007. http://dx.doi.org/10.1016/j.conbuildmat.2006.05.009

[3] Demir, I. \& Baspinar Serhat, M., Effect of silica fume and expanded perlite addition on the technical properties of the fly ash-lime-gypsum mixture. Construction and Building Materials, 22(6), pp. 1299-1304, 2008. http://dx.doi.org/10.1016/j.conbuildmat.2007.01.011

[4] Gencel, O., del Coz Diaz, JJ. \& Sutcu, M., Properties of gypsum composites containing vermiculite and polypropylene fibers: numerical and experimental results. Energy and Buildings, 70, pp. 135-144, 2014. http://dx.doi.org/10.1016/j.enbuild.2013.11.047

[5] Baspinar Serhat, M. \& Kahraman Erhan, N., Modifications in the properties of gypsum construction element via addition of expanded macroporous silica granules. Construction and Building Materials, 25(8), pp. 3327-3333, 2011. http://dx.doi.org/10.1016/j.conbuildmat.2011.03.022

[6] Garcia Santos, A., PPF-reinforced, ESP-lightened gypsum plaster. Materiales De Construccion, 59(293), pp. 105-124, 2009.

[7] Sayil, B. \& Gurdal, E., The physical properties of polystyrene aggregated gypsum blocks. In 8th International Conference on Durability of Building Materials and Components $(8 \mathrm{dbmc})$. Vancouver, Canada: Research Council Canada. Durability of Building Materials and Components 8, Vols. 1-4, Proceedings, pp. 496-504, 1999.

[8] Gonzáles Madariaga, A.F.J. \& Lloveras Macia, J., Mezclas de residuos de poliestireno expandido (EPS) conglomerados con yeso o escayola para su uso en la construcción. Informes de la Construcción, 60(509), pp. 35-43, 2008.

[9] Gutierrez-Gonzales, S., Gadea, J., Rodriguez, A., Blanco-Varela, M.T. \& Calderon, V., Compatibility between gypsum and polyamide powder waste to produce lightweight plaster with enhanced thermal properties. Construction and Building Materials, 34, pp. 179-185, 2012. http://dx.doi.org/10.1016/j.conbuildmat.2012.02.061 
[10] Gutierrez-Gonzales, S., Gadea, J., Rodriguez, A., Junco, C. \& Calderson, V., Lightweight plaster materials with enhanced thermal properties made with polyurethane foam wastes. Construction and Building Materials, 28(1), pp. 653-658, 2012. http://dx.doi.org/10.1016/j.conbuildmat.2011.10.055

[11] Serna, A., del Rio, M., Gabriel, P.J. \& Gonzalez, M., Improvement of gypsum plaster strain capacity by the addition of rubber particles from recycled tyres. Construction and Building Materials, 35, pp. 633-641, 2012. http://dx.doi.org/10.1016/j.conbuildmat.2012.04.093

[12] Herrero, S., Mayor, P. \& Hernandez-Olivarez, F., Influence of proportion and particle size gradation of rubber from end-of-life tires on mechanical, thermal and acoustic properties of plaster-rubber mortars. Materials \& Design, 47, pp. 633-642, 2013. http://dx.doi.org/10.1016/j.matdes.2012.12.063

[13] Jimenez Rivero, A., de Guzman Baez, A. \& Garcia Navarro, J., New composite gypsum plaster - ground waste rubber coming from pipe foam insulation. Construction and Building Materials, 55, pp. 146-152, 2014. http://dx.doi.org/10.1016/j.conbuildmat.2014.01.027

[14] Hernandez-Olivarez, F., Bollati, M.R., del Rio, M. \& Parga-Landa, B., Development of cork-gypsum composites for building applications. Construction and Building Materials, 13(4), pp. 179-186, 1999. http://dx.doi.org/10.1016/S0950-0618(99)00021-5

[15] Colak, A., Density and strength characteristics of foamed gypsum. Cement \& Concrete Composites, 22(3), pp. 193-200, 2000. http://dx.doi.org/10.1016/S0958-9465(00)00008-1

[16] Rubio-Avalos, J.C., Manzano-Ramirez, A., Yanez-Limon, J.M., Contreras-Garcia, M.E., Alonso-Guzman, E.M. \& Gonzalez-Hernandez, J., Development and characterization of an inorganic foam obtained by using sodium bicarbonate as a gas generator. Construction and Building Materials, 19(7), pp. 543-549, 2005. http://dx.doi.org/10.1016/j.conbuildmat.2004.12.001

[17] Knott, E.D., Foaming plaster. Patent US 20090324931, 2005.

[18] Gamarra Ch. Method of making aerated gypsum and resulting product. Patent US1912702, 1933.

[19] Stahl, D. \& Puchel, E., Process for preparing foamed gypsum and constructional elements composed thereof. Patent US 4153470, 1979.

[20] Saito, M., Hirai, E., Endo, M. \& Nishino, T., Foamed gypsum moulded articles and production thereof. Patent US 4330589, 1982.

[21] Vimmrová, A., Nazmunnahar, M. \& Černý R., Lightweight gypsum-based materials prepared with aluminum powder as foaming agent. Cement Wapno Beton, 19(5), pp. 299-307, 2014.

[22] Vimmrová, A., Keppert, M., Svoboda, L. \& Robert, C., Lightweight gypsum composites: design strategies for multi-functionality. Cement \& Concrete Composites, 33(1), pp. 84-89, 2011. http://dx.doi.org/10.1016/j.cemconcomp.2010.09.011

[23] Larionov, M.T. \& Filakhtova, E.A., Kompozicija dlja izgotovlenija gazogipsa. Patent SU 857044, 1971.

[24] Mazur, S. \& Kolarz, B., Sposób wytwarzania gazogipsu. Patent PL 54325, 1966.

[25] Bazelova, Z., Pach, L. \& Lokaj, J., The effect of surface actice substance concentration on the properties of foamed and non-foamed gypsum. Ceramics-Silikáty, 54(4), pp. 379-385, 2010. 
[26] Akthar, F,K. \& Evans, J.R.G., High porosity (>90\%) cementitious foams. Cement and Concrete Research, 40(2), pp. 352-358, 2010. http://dx.doi.org/10.1016/j.cemconres.2009.10.012

[27] Zheng, B., Titanium gypsum foamed building block and preparation method thereof. Patent CN 103467056, 2014.

[28] Brencis, R., Skujans, J., Iljins, U., Ziemelis, I. \& Osits, N., Research on foam gypsum with hemp fibrous reinforcement. In 14th International Conference on Process Integration, Modelling and Optimisation for Energy Saving and Pollution Reduction, Florence, ITALY: AIDIC SERVIZI SRL, Vol. 25, pp. 159-164, 2011. 